\title{
A Persian archery manual by Mohammad Zamān
}

\author{
Manouchehr Moshtagh KHORASANI*1 \& Bede DWYER² \\ ${ }^{1}$ Razmafzar: Historical Persian Martial Arts Organization (Germany) \\ ${ }^{2}$ Razmafzar: Historical Persian Martial Arts Organization (Australia)
}

Recepción: 13/05/2016; Aceptación: 20/06/2016; Publicación: 21/06/2016.

\section{Abstract}

Persian archery manuals provide lots of useful information on shooting with a Persian composite bow. The main aim of this article is to provide, for the first time, a full annotated translation of an undated Persian archery manual written by Mohammad Zamān known as Čerāq Beg from the family of Kāmrān Beg Qarānāj. The manual is handwritten and consists of twenty four pages which include twelve chapters. Despite the occasional confusion, the obscure vocabulary, and the odd clumsy description, the text is a mine of information. It shows the continuity of the Persian archery tradition at least to the end of the eighteenth century and increases our knowledge of some of the details once commonplace that are now obscure. The gradual increase in our knowledge of Persian archery is progressing through the discovery and translation of works like this one of Mohammad Zamān. Such manuals introduce new techniques and also confirm the pervasiveness of the basic forms of this ancient art.

Keywords: Persian martial arts; historical martial arts; Persian bow; composite bow; archery.

\section{Un manual de tiro con arco persa por Mohammad Zamān}

\section{Resumen}

Los manuales de tiro con arco persa proporcionan mucha información sobre cómo disparar el arco compuesto. El objetivo principal de este artículo es ofrecer, por primera vez, una traducción completa y comentada de un manuscrito persa sin datar sobre tiro con arco, escrito por Mohammad Zamān, conocido como Čerāq Beg, de la familia de Kāmrān Beg Qarānāj. Está escrito a mano, tiene veinticuatro páginas y se compone de doce capítulos. A pesar de ser confuso en ocasiones, utilizar un vocabulario poco claro, y realizar descripciones poco precisas, el texto es una mina de información. Muestra la continuidad de la tradición persa de tiro con arco al menos hasta finales del siglo XVIII y aumenta nuestro conocimiento de algunos de los detalles antaño conocidos pero ahora más oscuros. El aumento gradual de nuestro conocimiento sobre el tiro con arco persa está progresando gracias al descubrimiento y la traducción de obras como la de Mohammad Zamān. Dichos manuscritos introducen nuevas técnicas y también confirman la omnipresencia de las formas básicas de este antiguo arte.

Palabras clave: Artes marciales persas; artes marciales históricas; arco persa; arco compuesto; tiro con arco.

\section{Um manual de tiro com arco persa por Mohammad Zamān}

\section{Resumo}

Os manuais sobre o tiro com arco persa proporcionam muita informação sobre o modo de disparar com um arco composto. $\mathrm{O}$ objetivo principal deste artigo é oferecer, pela primeira vez, uma tradução completa e comentada de um manuscrito persa, sem data, sobre tiro com arco, escrito por Mohammad Zamān, conhecido como Čerāq Beg, da família de Kāmrān Beg Qarānāj. O manuscrito tem vinte e quatro páginas e doze capítulos. Apesar de ser ocasionalmente confuso, utilizar um vocabulário pouco claro e realizar descrições pouco precisas, o texto é uma "mina" de informação. Ele mostra a continuidade da tradição persa do tiro com arco até, pelo menos, finais do século XVIII e aumenta o nosso conhecimento sobre alguns detalhes até agora desconhecidos. 0 aumento gradual do nosso conhecimento sobre o tiro com arco persa está progredindo graças ao descobrimento e tradução de obras como a de Mohammad Zamān. Os manuscritos introduzem novas técnicas e também confirmam a onipresença das formas básicas desta arte ancestral.

Palavras-chave: Artes marciais persas; artes marciais históricas; arco persa; arco composto; tiro com arco.

\section{Introduction}

Archery always played an important role throughout the military history of Iran. Many kings of Ancient Persia took pride in displaying their archery prowess, such as Darius (549-486 BCE), who in his edict (Bande 9) in Naqš-e Rostam wrote, "I am skilled with my both hands and feet.

*E-mail: manouchehr@moshtaghkhorasani.com 
I am a good rider, I am a good archer on foot and on horseback, I am a good spearman on foot and on horseback"1. Later during the Islamic period of Iran, archery kept its importance. European travelers to Safavid Iran report on the skills and prowess of Šāh Esmāil Safavid in shooting with the bow. It is reported that he hit 12 apples with his arrows without missing even once. ${ }^{2}$

It is certain that archery was systematically trained in different eras. Also, that Persian archery manuals provide lots of useful information on shooting with a Persian composite bow. The main aim of this article is to provide, for the first time, a full annotated translation of an undated Persian archery manual written by Mohammad Zamān known as Čerāq Beg from the family of Kāmrān Beg Qarānāj. This archery manual by Mohammad Zamān consists of twelve chapters. First chapter is about the thumb, the training bow and shooting leys. The second chapter is about shooting with an earth arrow. The third chapter is about the flight shooting arrow. The fourth chapter is about different types of arrow and their related field of application. The fifth chapter is about the bow and arrows. The sixth chapter is about stringing the bow for shooting leys and shooting with other arrows. The seventh chapter is about shooting with a sapling arrow. The eighth chapter is about the length and type of arrows. The ninth chapter is about making the earthen butt. The tenth chapter is about four different types of bow and mounting them. The eleventh is about shooting in ox kasmal. The twelfth is about shooting the qapaq. The manual has only one small illustration of a bow shown on page 23 of the manual (see Picture 2).

\section{Method}

The manuscript object of study is kept in the Malek Library in Tehran, Iran, and consists of twenty four pages. It is handwritten in Persian and judging by some part of the text it should have been written by a Persian in India. One of the authors of the present article, Khorasani, translated the text from Persian into English and then both authors compared the text to historical and current literature on Persian archery. The authors of the present article have already analyzed and published four other Persian archery manuals: a) Resāle-ye Qosnāmeh (Archery Manual) (see Dwyer \& Khorasani, 2015), b) an archery manual collected by by Kapur Čand (Dwyer \& Khorasani, 2013), c) A Persian Manuscript on Archery, Spear Fighting, Sword Tempering and Lance Fighting and Horsemanship by Šarif Mohammad the Son of Ahmad Mehdi (Khorasani \& Dwyer, 2012) and Jāme al-Hadāyat Fi Elm al-Romāyat [Complete Guide Concerning the Science of Archery] (Dwyer \& Khorasani, 2012). Further one of the authors of the present article published a book titled Persian Archery and Swordsmanship: Historical Martial Arts of Iran which included all above-mentioned Persian archery manuals. Additionally, the book included a chapter from the book Nŏruznāme [The Book of Nŏruz] on archery dated to the 11th century and attributed to Omar ibn Ibrāhim Khayyāme Neyshāburi (Khorasani, 2013).

\section{The complete translated text of the Persian archery manual by Mohammad Zamān}

In the name of God, most benevolent, ever-merciful. All the praises be to God. ${ }^{3}$ Greetings be upon the Prophet Mohammad and his family. This is a manuscript on archery which has been written by this humble person Mohammad Zamān known as Čerāq Beg from the family of Kāmrān Beg Qarānāj. ${ }^{4}$ Whatever this lowly person has experienced and tested is written in this manuscript. I learned the art of archery in childhood from my deceased father, God bless his soul and keep his grave clean, and bring him to the eternal paradise. I have been learning this art into my old age. Some masters of this craft, God bless their souls, decided to record their art known as "Selection of our Period" so that people who are seeking to learn this craft and techniques pray for the collector of these [scripts] and remember them with clear memory. This manuscript consists of twelve chapters. First chapter is about the thumb, the "training bow"5 and leys andāxtan ${ }^{6}$. The second

\footnotetext{
1 See Sharp (1964, p. 85).

2 See Mir'i (1970, p. 205).

3 It is the second verse of the first Surah of the Qur'an "Al-Fātihah".

4 There is a Karanai north of Azerbaijan.

5 kabbāde كباده.
}

Rev. Artes Marciales Asiát., 11(1), 48-65 2016 
chapter is about shooting with an "earth arrow"7. The third chapter is about the "flight shooting arrow" 8 . The fourth chapter is about different types of arrow and each arrow type should be used at its own place. The fifth chapter is about the bow and arrows. The sixth chapter is about "stringing the bow" for leysandāzi and shooting with other arrows. The seventh chapter is about shooting with a "tir-e bote" (sapling arrow). The eighth chapter is about the length and type of arrows. The ninth chapter is about making the "earthen butt"9. The tenth chapter is about four different types of bow and mounting them ${ }^{10}$. The eleventh is about shooting in ox kasmal11. The twelfth is about shooting the qapaq $^{12}$.

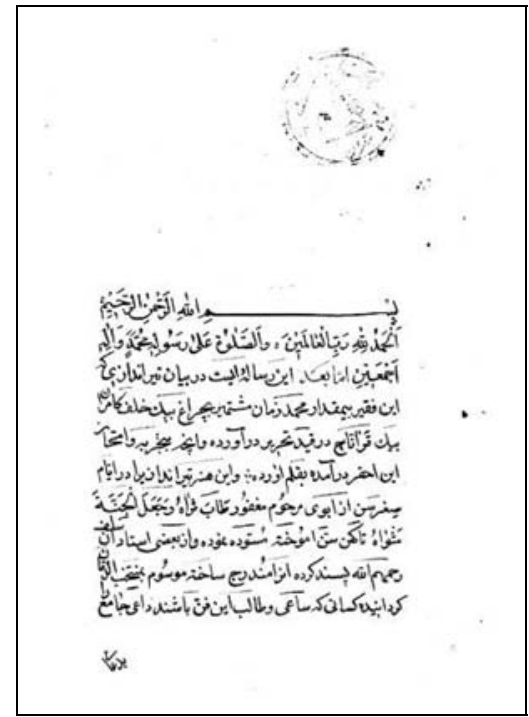

Picture 1. The first page of the manuscript.

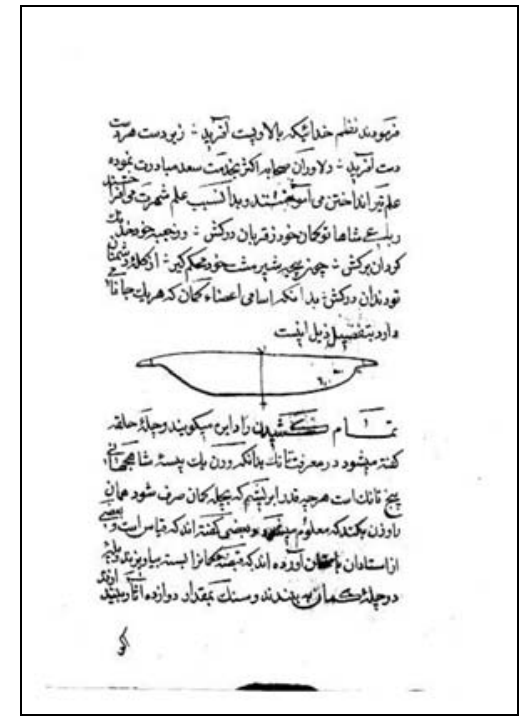

Picture 2. The page 23 of the manuscript showing a drawing of a bow.

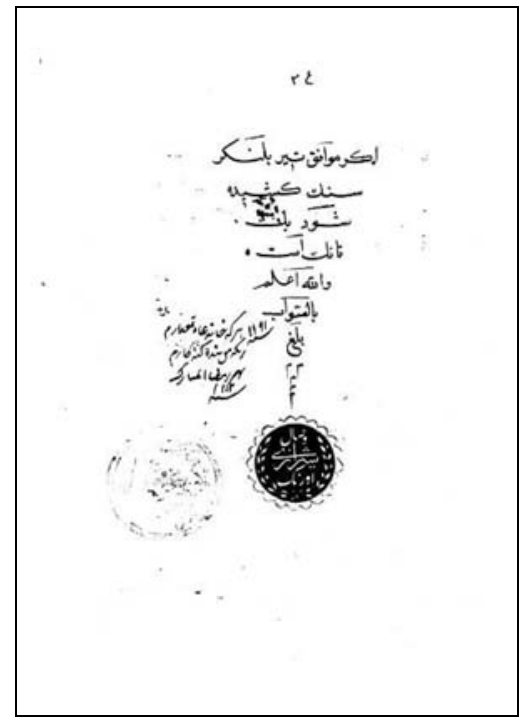

Picture 3. The last page (page 24) of the manuscript with dates and the deal of Vesāl Širāzi.

\section{First chapter}

Is about the thumb, training bow and leys ${ }^{13}$. First the bow should have short arms and its horn should be sawn and made with the width of two fingers so that it is very soft. ${ }^{14}$ They hold this bow, stand up in a way that the right leg is behind and the left leg is forward. The left arm is extended like a column and with the right hand he pulls the string to the moustache level so that it reaches the right earlobe. ${ }^{15}$ There are four types of pulling the bowstring: eyebrow draw ${ }^{16}$,

\footnotetext{
${ }^{6}$ lis andāxtan ليسانداختن. [In The Traditional Crafts of Persia] (Wulff, 1966, pp. 84, 87, 101), the wood scraper or carver's scraper is called liseh (ليسا) and it was used for scraping, smoothing and polishing. There may be some connection such as the sense of smooth or finished shooting.

7 tir-e xāki تير خاكى. According to the Digital Lexicon of Dehxodā, this is a small arrow with a light bone arrowhead that flies the furthest.

8 tir-e partāb تير باجناب.

${ }^{9} \bar{a} m a \bar{j}$ آمان.

10 Later in the text, the author mentions "Shooting at the foot of a bush" as the tenth chapter.

11 This could be from the Turkish word kesmek meaning to cut. I also remember that the Turkish word for arrow, $o k$, was written in Chagatai as auq (aق). It could be that the word derived from a phrase meaning to cut arrows, i.e., shooting at an arrow like target to cut it into pieces.

12 قجن 12 it is a long wooden stick/pole planted in the city square on which a plate full of golden coins was placed which the mounted archers tried to shoot down while riding at full gallop; if the plate was shot down, the bowman could win a large prize. This is the kabak of the Turks and the qabaq (قبق) of the Arabs and Mamluks.

13 ليس.

14 This is roughly $40 \mathrm{~mm}$ wide so this bow did not have separate strips glued parallel to each other similar to other Persian bows. This is also narrow for a standard Persian bow. Chahar Kham bows (McEwen, 1979) from India usually have one strip of horn per limb and they are mentioned in other Persian texts.

15 This is a classic draw for the Middle East and target and military archery.

16 abrukeš بروكش.
} 
moustache draw ${ }^{17}$, beard draw ${ }^{18}$ and side of the body draw ${ }^{19}$. But as the good things are in the middle way they should act upon the teachings of old masters and use the moustache draw. The aim is to draw to the earlobe and the hand should not drop, otherwise this will be called beard draw. This is a mistake which will become evident by the following couplet by a master:

There are "eyebrow draw", beard draw and moustache draw

Place on the eyebrow, on the beard but do the moustache draw 20

Upon drawing the bow, he should not pout, should not bite his lips and should not frown... ${ }^{21}$

You should keep the bow limb 22 in the right position and does not slant to any side. They should use the bow this way. It is also said that the "training bow" 23 is necessary. They should draw this type of bow slowly and it is not good to draw it fast. They should draw it so slowly as if they were removing a hair from the dough. They should keep three fingers of the hand grasping the bow handle tightly, namely the thumb ${ }^{24}$, the middle finger and the ring finger ${ }^{25}$ so that the blood collects in their finger tips. The index finger ${ }^{26}$ and small finger ${ }^{27}$ are kept loosely. ${ }^{28}$ The following couplet shows how the right hand holding the thumb ring and the arrow should be held. The poem:

Two are held tight three loose and three tight and two loose. ${ }^{29}$

This is the way of the master. Drawing the bow with the right hand should be done slowly. The more one places power in the left hand, the better it is. The majority of masters place their students in front of a wall so that the shoulders and the back touch the wall and there should be no distance. When he places the left leg forward the left side of the body should stick to the wall from outside and when he places the right leg behind it should be close to the wall. He should not keep his left leg stiff but should keep his right leg strong. ${ }^{30}$ This way one can become a master. The more he draws a training bow the better it is. After that he should also draw a weak bow and shoot with it. But one should not exhaust the hand because exhaustion causes problems. This way he increases the power of the bow day by day so that he reaches the level of a strong bow. Each time the archer is stronger than the bow, he shoots better; otherwise he will not be able to show his skills. ${ }^{31}$

Shooting with the thumb is better. The intention of shooting with the thumb is to use a thumb protector. There are four types of thumb protectors. The first type made of gold is strong. The second one is made of patterned crucible steel. ${ }^{32}$ The third one is made of walrus ivory without

\footnotetext{
17 borutkeš بروت

18 riškeš ريشكش. It probably means drawing to the level of the beard along the jaw to the angle of the mandible near the ear.

19 baqalkeš بغلكش.

20 The last line could mean while drawing you can pass either the eyebrow (drawing down from above) or the beard (drawing up from below), but always finish the draw at the level of the moustache.

21 The instruction is to be calm and mentally relaxed and the external signs of tension are not to be exhibited.

22 xāne-ye kamān خانه كمان.

23 kamān-e kabbāde كمانكباد. In Turkish the training bow is kepade and Arabic has the same spelling as Farsi, but with a different pronunciation. Practice bows were used to develop form and muscle memory so that as the archer's strength increased he would still pull the bow and release it with the correct technique.

24 ebhām ابهام.

25 benser بنصر

26 šahādat شهادت.

27 xenser خنصر.

${ }^{28}$ Normally, one holds the small finger, ring finger and middle finger of the bow hand tight and the thumb and the index finger loose; three tight two loose. But in the changal-e baz the thumb can be tight if necessary.

29 One tight, one loose, three tight could describe a tight thumb a loose index finger and tight middle, ring and small fingers. Other older authorities like Šarif Mohammad (Khorasani, 2013, p. 68) are very explicit and so are the Arabic and Turkish authorities.

30 Using the wall is mentioned in Saracen Archery (Latham \& Paterson, 1970, p. 56) as a way of measuring the draw. This is the first description of using the same technique to teach posture to a beginning archer.

31 This paragraph is very solid advice and matches other descriptions of the process of developing strength and skill shooting the bow.

32 There is one in the Grayson Collection.
} 
black spots ${ }^{33}$ so that it is not brittle. ${ }^{34}$ The fourth is made of horn either black or white and if it is made of both colors (black and white), it looks better. ${ }^{35}$

There are also different types of thumb rings. First type is "half oval" 36 . The second type is "like a hoof" 37 . Third type is "Kazak type"38. The fourth type is "duck's beak" 39 . The fifth one is like a "hat resembling a boat" 40 . In my opinion, the half oval type is the best. This is made in a way that if two thumb protectors of this type are placed next to each other where the head of each is placed next to the bottom of the other, they resemble an egg. This type should be carved in a way so that its breast remains empty. Its rims should be round so that it does not ruin the bowstring of the bow. This happens due to a lack of knowledge. The inside of the thumb ring should be empty so that the thumb is not stifled. It should be a bit loose so that it can be taken off. For the sake of bow, the thumb ring was invented.

\section{Second chapter}

About shooting the earth arrow. Some call the earth arrow "like a wasp" 41 . Shooting it requires lots of skills. The bow used to shoot the earth arrow should be short. The circumference of the bow is rounded and its bowstring should be made a bit longer so that it sticks to the "heads [ends] of the bow"42.43 In shooting, they should not keep the bow heating by fire so long so that it upon drawing it tears apart from the bow ears to the bow grip. Its bowstring is thinner compared to the bowstring of the bow for leysandāzi. The bow should dominate the bowstring. ${ }^{4}$ The length of the bow should be thirteen and half fists. The length of the earth arrow should be nine fists minus one finger and is fletched with three feathers made of "vulture's feather" 45 and each is five fingers long. ${ }^{46}$ Its arrowhead should be half of a pea long. ${ }^{47}$ The target for the earth arrow should be placed at a distance of two hundred and fifty "principal steps" 48 . The principal step is measured when a

33 māhi-ye bijohar ماهىييجوهر. There is one in the Dwyer Collection.

34 The best rings are made of walrus tusk, because this material takes a good polish and does not turn yellow. Ivory is a permissible material and does not interdict the saying of prayers when carried in the pocket; but turns yellow quickly (Klopsteg, 1987, p. 68). The superiority of walrus ivory to elephant ivory may also have relied on the interesting crystalline pattern of the dentine which is visible in most large pieces.

35 There is one made of black horn and ivory combined in the Dwyer Collection. This is what may be meant or mottled horn which is also very attractive.

36 nimbeyze نيجبيضه. The half oval type is a common type and are very effective.

37 somi سمى. The ones which look like a hoof resemble Ottoman ivory rings for flight archery. These also work well.

38 qazāqi قز قاقى Kazak originally meant nomadic freebooters. It could also be used for the three Kazak hordes which took the name when they split from the Uzbeks in the $18^{\text {th }}$ century. The Kazak thumb ring type may be similar to the small ring in the famous portrait of Mohammad Šaybani Xān Uzbek (Metropolitan Museum of Art Accession No. 57.51.29).

39 bate nul بطنول. Some Indian archer's rings of the Moghul period have a broad lip which does not come to a point, but is rather straight across the tip resembling a duck's beak. They can be slightly convex near this area of the lip. One of the authors of the article, Dwyer, has seen pictures of the duck beak type from India and thinks they behave like the flat oval ones from Iran.

40 zoraqi ذورقى. The one resembling a hat is similar to a jade one shown in a painting of Bahrām Gur and the dragon by Mohammad Zaman (The British Library Or. 2265, fol. 203v.). This is also good to shoot with but a little bulky if switching to a sword. Compare the list of thumb rings in the Ādāb al-Harb by Fakhr-i Mudabbir: "There are several kinds of thumb ring, 'warrior-style' (ghāzivār), 'princely-style' (mīrīvār), and the Turkish-style' (turkīvār)...' (McEwen, 1974, p. 85).

مخهى 41 maxhi.

42 kalle-ye kamān كلدكمان.

43 The circumference of the bow could refer to two things: the cross section or the shape of the unstrung bow. Either would be valid because a deeper (more rounded) cross section would give a faster shooting bow and a more rounded reflex would also contribute to the speed of the bow.

44 Thin bowstrings are preferred for distance shooting because they weigh less. Some archers preferred thick strings for target archery because they thought them more accurate.

45 par-e karkas بِركركس.

46 Ottoman heki oku are shown in Türk okçuluğu (Yücel, 1998, p. 185) with feathers longer than flight arrows but shorter than target arrows. In the text is says they are 40.5-64.5 mm long which is what can be seen in collections. This is smaller than the Persian ones but the Turkish arrows were to be shot from a siper and were shorter.

47 This is very close to the azmayiş arrow in the Grayson Collection which has a tiny metal point with a fine $20 \mathrm{~mm}$ tang inserted in the shaft.

48 qadam-e asli قدماصلى. 
pregnant wife walks the measured distance carrying a water jug. ${ }^{49}$ The earth arrow should be shot at the height of a camel rider. ${ }^{50}$ But this is difficult. Therefore, any lower level than this is better and shows the skills of the archer. He should not shoot it at an "astronomical elevation" 51 nor in a parabolic ${ }^{2}$ line. As these are mistakes and cause the arrow to shake and wobble as it leaves the bow arms. ${ }^{53}$ The whole arrow should be hidden behind the nock [when it leaves the bow]. ${ }^{54}$ It is said that the chest of the arrow should be visible when it leaves the bow. 55 The target which is placed at two hundred fifty steps is made of cane with a width of one $g a z^{56}$ and the length of ..... ${ }^{57}$. This is called $n \bar{a} q i^{58}$ in Indian language. They put a red cover over the target and fasten it with white fabric tightly so that the target is visible from the distance. They place the $n \bar{a} q i$ target on a surface ground which has no risings and even. They pour some earth on it so that so that when the arrow hits the target the earth which falls down the ground is one span above the ground. ${ }^{59}$

\section{Third chapter}

It is about shooting the "flight archery arrow"60. The bow for doing this should have short bow arms. ${ }^{61}$ It is thirteen and half fists long. The bow used for flight archery is stronger than the "bow used to shoot earth arrow"62. They string it with a narrow bowstring made of silk. In contrast to the $k a z \bar{a} k^{63}$ style, the mirzāi $i^{64}$ style is better way to put the string on the bow. There is no difference in the type of bowstring used for the string for the bow of earth arrow and the string for the bow for flight shooting. It should be twisted and tightened that hard that if they unstring the bow, the bowstring behaves rigid like a piece of wood. 65 The length of the flight archery arrow should be nine and half fists and is fletched with "vulture's feather" 66 and each is three fingers long. Sometimes they say it should tend to be whitish.

The shaft of this arrow is very light, narrow and hard so that the wind does not shake it. Its arrow nock should not be wide. When drawing this bow, they should divide the sky in three parts, two parts should be left behind the head and one part in front of the head. ${ }^{67}$ He should stay strong.

49 It means that it was less than a standard step because in general women are smaller than men and a pregnant woman with a jug on her head would step very carefully.

50 It means that the target is at the height of a camel rider.

51 setāreriz ستار مريز

52 gonbadi كنبدى, literally, it means with the trajectory matching the outline of a dome.

53 This could mean that it should be shot with a flat trajectory though this does not explain the shakes and wobbles.

54 This would be from the view of the archer. It means the arrow is travelling exactly along the line of sight with no wobbling whether vertically or horizontally.

55 This could mean that the arrow is ascending in relation to the line of sight of the archer.

56 A length measurement, circa one meter (Digital Lexicon of Dehxodā).

57 The word is missing in the manuscript.

58 ناقى 58 it could be the name of a target of this type or refer to the cane it is made from. However, there is a Hindi word, नर्कत, (narkat) that means reed. So this could be the origin though losing the "r" sound would be a problem.

59 This appears to mean that the dust is disturbed when the arrow hits the target and may be the visual cue that the target has been hit. At a standard pace, it would be 190.5 meters distant. We can assume less because of the smaller pace. A thin arrow like the earth arrow would not be visible in the target. The Koreans use a target 1.8 meters wide at 140 meters so the width of the naqqi target is smaller than this. The Koreans rely on a spotter on the same level as the target to signal it has been hit.

60 tir-e partāb تيريرناب.

61 If the author is using xāne for bow arms, I think we should indicate the bending sections of the arms are shorter than usual. If he means the whole bow limb, he is talking about a physically shorter bow. Both are true and xāne can mean either.

62 kamān-e xāki كمانخاكى.

63 qazāqi قز 64 .

ميرزائى 64.

65 There has been some discussion among modern flight archers of the benefits of a stiff string.

66 par-e karkas بركركس:

67 If one takes the sky to be $180^{\circ}$, then one third of the sky would be $60^{\circ}$. The modern and ancient consensus for flight shooting is that the best angle is $42^{\circ}$ to $45^{\circ}$, depending on the conditions. It is possible that there was originally more text in this section which may be a quotation from another authority. It could also be that this is the rough estimation by the author. 
One hand is in the same line with the shoulder of the archer and the right hand starts below the level of the right armpit. They keep the left hand very strong so it does not fall back. They should take one step back with the arrow as if the bow is pulling them back. ${ }^{68}$ Flight archery requires continuous training. ${ }^{69}$

\section{Fourth chapter}

It is about different types of arrows. Each type of arrow should be used for a specific purpose. The first type has an "arrowhead with four edges"70. Its arrowhead is three fingers long and is hardened along its length. Its arrow tang ${ }^{71}$ is four fingers long and is not hardened. It is fastened to a shaft of cane using three "layers of sinew"72. This can be shot at bil and tābe. There are two types of arrow for shooting at a shield. The first type is an arrow with a rounded "iron arrowhead"73. Half of the arrowhead should be hollow. It is not shot very hard like a broad head arrow (bil). The second type is atqu ${ }^{74}$ which is a Turkic word and means "going" 75 . Its arrowhead is made of conical stag horn with a length of two fingers. Its tang is made of olive wood with a length of three fingers. Using a strong bow, the $\bar{a} t q u$ arrow can pass through two shields. ${ }^{76}$

The next one is čāl arrow similar to quštili77. This is also a Turkic word. Quš means falcon and tili means in other words "small almond" meaning like an almond. This arrowhead is trilobed ${ }^{78}$. The other type is crescent-shaped ${ }^{79}$ which is called čandratiyān in Indian language. It is used to shoot down the fruit down from the trees ${ }^{80}$, to shoot at the snake's head, to cut the bowstring of the enemy's bow and to extinguish the fire of the candle. ${ }^{81}$ The ča $\bar{a} l$ arrow is used in all situations [.]: for the packsaddle ${ }^{82}$, for [shooting at] two-layered armor ${ }^{83}$, for hunting and sometimes for silo ${ }^{84}$.

The other type is used to break stones which has a length of two fingers and a tang of four fingers. It is used like tir-e beyl ${ }^{85}$. But unlike tir-e beyl, it is not hollow. The stone which is used to be shot at should be red hot. In Indian it is called sangari.

Another type is an arrowhead resembling a "snake's head" 86 with four sides. Its tang has eight sides. It is used against armor or bagtar ${ }^{87}$.

\footnotetext{
68 This sounds like some form of leaning back as one elevates the bow hand to get the correct angle. Flight archers do everything possible to maximize the distance. It is unlikely that one would step back from the shooting line, but moving the back leg into a better position is a good technique.

${ }^{69}$ Specialized and intensive training is a necessity to manage the fast draws and heavy bows.

70 peykān-e čăhrpahlu ييكانجهاريهل This is more likely to be a four sided arrowhead. The targets seem to be spades and pans. A four-sided pyramidal arrowhead is good for shooting sheet metal.

71 dombāle دنباله.

72 se pey سنيّ.

73 āhanin peykān آهنينيكان.

74 آثقا. In modern Turkish, atkı means something like a scarf or warp or weft in weaving. It might be Chagatai Turkish since the Moguls spoke this in the family originally.

75 ravande روند.

76 These are peculiar arrowheads. One is hollow and the other is antler. Neither is likely to penetrate a shield, assuming a standard hide shield used in Iran and India. The descriptions better fit whistling arrows rather than shield piercers.

77 قوشنيلى kuş dili in modern Turkish means "bird's tongue" though it can mean bird language.

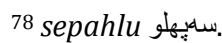

79 helāli هلإلى

80 This is a new use for archery.

${ }^{81}$ Cutting the enemy's bowstring is mentioned in several cultures. This and shooting out a candle flame may be standard trick shots meant to show an archer's skill at a festival.

82 xugir خوكير.

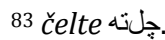

84 nokba نكبه

85 An arrow type which has an arrowhead resembling a shovelhead (Digital Lexicon of Dehxodā). This is a recognized type of broad head in India; the small version is called bilak. The later reference to it being hollow may refer to the openwork broad head resembling a stylized Indian knife, the katar (McEwen, 1974, Fig. 2, 1)

86 mārsar مارسر.
} 


\section{Fifth chapter}

About the bow and the length of the arrow for the archer. They need four types of bows. First a short bow with three layers of sinew. ${ }^{88}$ It is of thirteen and half fists in length and two fingers in width. It should be of at least three to four years old. The bowyer places the first layer of tendon and keep the bow for one year. The second year he places the second layer of tendon. The third year it will be finished. The sign of dryness is that when they place the "loop of the bowstring" 89 on the nocks, the whole surface of the bow starts to crack. ${ }^{90}$ Each time, they unstring the bow, it becomes a half circle. Its arrow is very fast. ${ }^{91}$ Second the bow for shooting earth arrow with short arms has a rounded circumference. Third a bow for flight shooting as already explained. Fourth a bow with a length of fourteen fists for shooting "war arrows"92 because it has long bow limbs.

\section{Sixth chapter}

About four different types of bow. First "four curves"93, second the "middle circumference" 94 , third "even circumference"95, fourth "crescent-shaped circumference"96.97 For "shooting a war bow" 98 and "power shooting"99, they use a bow with four curves. For shooting leys ${ }^{100}$, they use a bow with a middle circumference. ${ }^{101}$ For shooting a earth arrow, they use a bow which has an even circumference, although some masters prefer a bow with a crescent-shaped circumference, but the latter type remains good for some days and then loses its power. What this humble self has experienced is that bows with a middle circumference or even circumference are good for shooting. Another thing is that the bow should have a set towards the back. ${ }^{102}$ In the course of time, this hardness gets softer. ${ }^{103}$ Without this set towards the back, the bow becomes less powerful fast and this is the opinion of this humble self. But the archers who are not powerful do not like this. ${ }^{104}$ Archery depends on power.

Based on the proper calculation, the bow should be thirteen and half fists long105 and its arrow should be eight and half fists long. 106 They should place the arrow on the side of the bow grip

87 بكتر; Denxodā states that this is a type of armor made of different iron plates covered with velvet. A bekter in Turkish and Russian is an armor made of small horizontal plates linked by vertical bands of mail. It is usually just a cuirass worn over a mail shirt.

88 The purpose of the bow is not explained. Whatever the purpose of this bow, it would be a very strong bow.

89 halqe حلقه.

90 This can be the noise of cracking which is internal stress in the thick glue or it could be the layer of glue on the surface actually cracking. Neither is a fault. Modern composite bow makers are familiar with it.

${ }^{91}$ Becoming highly reflexed again after unstringing suggests a very powerful bow and a fast arrow is a consequence of the construction.

92 tir-e tarkeši تيرتركثى. It literally means "arrow from the quiver". This would be conventionally translated as war arrows as this is the implication in other manuscripts translated by one of the authors of this article. As a result the 14 fist bow would be a war bow. The degree that the bow is longer is very slight, but it would make a difference.

93 čārxam جֶارخم. This is similar to the eighteenth and nineteenth century Sind bow see (McEwen, 1979).

94 miyāndor مياندور. This note and the following two are referring to slight variations in the reflex profile of the unstrung bow. They may not mean what they first appear to. This could mean a bow that is reflexed near the handle (i.e., middle) rather than a medium degree of reflex.

95 hamvärdor همواردور. This could mean a bow with an even reflex with no sudden changes of angle.

96 helāldor حلالدور This might be similar to the Ottoman shape.

97 This suggests that circumference is being used to describe the profile of the unbraced bow. The Turks likewise had technical terms for these different profiles. They were kabza kuram, tekne kuram and hilâl kuram or grip shaped, boat shaped and crescent shaped, (Yücel, 1998, p. 241).

98 tarkeši تركثى.

99 karandāzi كراندازى This could be the equivalent of the Turkish zarb shooting.

100 tirandāzi-ye leys تير اندازىليس.

101 The middle circumference could be the same as kabza kuram.

102 It is unclear whether he means a general reflex or a specific handle reflex. There is some ambiguity in the descriptions because of lack of detail. Many surviving Persian bows show some handle reflex when unstrung.

103 This could be a statement about the loss of reflex in a bow when it has been strung for some time.

104 It is still true today. Setback gripped bows are harder to string and need more care to keep from warping. The most archers want easy to manage bows.

105 It is $112.2 \mathrm{~cm}$. 
at a point below the feathers and draw the bow open until the arrow tip reaches the bow grip. Whatever remains more than that is too much. The same principle applies to the earth arrow. Although the flight archery arrow which is three fingers longer ${ }^{107}$ is harder to shoot and therefore, one should learn flight shooting from a master. Although by reading manuscripts, one can understand it, an unbiased master is required. A bow which has a twist in its grip or has risings on each side is deficient. The bow grip should be a bit thick as a thin one is not good and will get loose fast. ${ }^{108}$ The bow should not have dents, cracks and crevices as these are the deficiencies of a bow.

\section{Seventh chapter}

Stringing a bow for leys shooting, earth arrow shooting, flight shooting, etc. For shooting a leys arrow, they should take thin silk and according to the power of the bow, twist the bowstring. Its component threads should be neither very thin nor very thick and should be strong. They are moistened, twisted together and they put some wax on the string. Then they press the nap and hide it in the bowstring by using a knife. Then they close it and put some water on it. Then they get some raw silk threads, twist them and tie them Kazāk style. [There are three styles of tying:] Kazāk style, Mirzāi [princely] style and half Kazāk style. ${ }^{109}$ In the Kazāk style, they twist the threads equal to the [thickness of a] thumb ring. The half Kazāk style has the half of its thickness which is also twisted in the Kazāk style and is used for shooting the earth arrow.110 The Mirzāi style is good for flight archery. The Mirzāi bowstring consists of five threads which are twisted together. The Mirzāi style is also good for shooting a war bow. ${ }^{111}$ The cord ${ }^{112}$ [bowstring] which is known as "lion's tail"113 is good during journey. But to find good silk is not easy, this lowly one does not trust in "bow strings from Māvard"114 which are made of silk.

Even the bow from Moltān is only very good for uninformed people. For archers, "Lahore bows"115 or "local bows with short limbs"116 are good. Otherwise, during "heavy rainfall"117, sayhune ${ }^{118}$, which is a name of a place in India, bows are better although they are not as good as "Lahore bows" or "local bows with short limbs" because sayhune bows are not affected and seldom stop functioning during heavy rainfall because they have lots of wood inside.119

\section{Eight chapter}

It is about the length of the bow and how to make it. Each side should be the same size as the other and should be measured exactly. Each bow ear should be three and half fingers. Each nock

\footnotetext{
106 It is equal to $70.7 \mathrm{~cm}$.

107 It means it is $70.7 \mathrm{~cm}+6.23 \mathrm{~cm}=76.93 \mathrm{~cm}$.

108 What the author may mean is it will distort because it is not strong enough to stay straight.

109 Often three styles of knotting the string are mentioned in comparable manuscripts. However, it is possible this part of the text is describing three different thicknesses of the separate end loops.

110 With separate end loops, it is possible to make them the thickness of the string to increase their robustness. Or they can be made the same thickness of the integral loop of the string (i.e., half the thickness of the whole string) which makes them lighter.

111 This is problematic if he is talking about the general construction of the string. A flight archery string is thin and hard and made as light as possible. This is not a good style for a war bow because it is inherently liable to break. A war bow string should be robust even if it loses some cast in the process. This leads to the possibility that the author is not talking about the strings but the knots used on them.

112 tasme تسمه Usually this means a strap or a belt.

113 Širdom شيردم.

114 čelle-ye māvardi جلمّماوردى.

115 kamān-e lāhuri كمان لاهورى

116 kamān-e velāyati-ye kutāhxāne كمانو لايتىكونامخانه.

117 barškāl برشكال.

118 Note that the Digital Lexicon of Dehxodā describes Sayhun as the river Jaxartes which is a river in Central Asia. But the text says that Sayhune سيهونه is a place in India.

119 For centuries there have been discussions on how the proportions of wood, horn, sinew, and glue affect the performance of bows in different climates. It is notable that some Indian composite bows have thin silver foil under the surface paint which might help waterproof them.
} 
should be one and half fingers. From the juncture of the ear and bow arm ${ }^{120}$ to the bow handle there should be a distance of five and half fists minus one finger. The "head of the bow"121 should be two fists long. The remainder makes up the bow limbs. The bow handle is one fist long. From one bow ear to the other the length should be thirteen and half fists. ............. This type of bow is good for shooting leys. For a bow with a length of thirteen and half fists, they need an arrow with a length of eight and half fists. The length of the house of its feathers should be seven fingers. The house of the feathers means the feathers here. The width of each feather should be one barley. ${ }^{122}$ The arrow shaft should be narrow and hard. From the arrowhead to the breast ${ }^{123}$ should be equal to ten fingers and the arrowhead should be four fingers longer so that it balances well. The weight of the arrow should be made in a way that the arrow should balance with a distance of thirteen fingers from the tip of the arrowhead. ${ }^{124}$ The best feathers are made of vulture feathers. The eagle feathers are good for arrows shot from the quiver. The feathers of ta'zari'25 which is an animal in India is only good to show off but are not of good quality. The other types of feathers should be only used when absolutely necessary. Because they are not very efficient because they are not hard, fast and powerful. Further the tendons of the bow with the mentioned bowstrings which were mentioned above. ${ }^{126}$ The proficiency in archery is reached by continuous training.

\section{Ninth chapter}

About earthen butt for the target meaning making the earth soft. They should take soft earth and remove the plant residues inside it. Then they make the target frame in a cubic shape with the same length, width and height. They should make sure that it is not built in a slanted angle. They should pour the earth for the height of one span on the foot of the earthen butt for the target, pour some water on it and then add more earth. Then they should stump on it. ${ }^{127}$ They continue the process until it reaches the required height of the earthen butt for the target. They carve out the face of the earthen butt for the target parallel to the wall and place some earth on it and hand rub it. The back of the earthen butt for the target should be loose and all parts should have the same hardness.

\section{Tenth chapter}

Shooting at the foot of a bush ${ }^{128}$. The foot of a bush is a type of target which is two sahar ${ }^{129}$. It resembles the foot of a bush. The lower they shoot at this type of target the better it is and this is the art of this type of shooting.

\footnotetext{
${ }^{120} \mathrm{kandegi}$ كندى, if this means the point of pulling away, it might mean the juncture of the ear and bow arm.

121 kalle-ye kamān كلنكمان.

122 The width of a barley grain used to be used in the English and Irish shoe trade as a measurement. It was $8 \mathrm{~mm}$. This is not an unusual maximum height for a feather on an arrow in Iran or India.

123 gereh-e tir كرنيز; this probably means the breast, i.e. the breast can be seen as a swelling of the shaft. In a barreled arrow the thickest part of the shaft is sometimes called the breast. Usually the nock is the same diameter as the thickest part of the shaft.

124 The balance point of an arrow reflects its usage. If the target is close, one wants the arrow to balance nearer its head so that the leverage of the feathers is increased and it straightens its flight more quickly. For a distance arrow, there is more time for the arrow to straighten out so its balance point can be nearer the geometric center of the arrow. In flight shooting, release technique is so important that usually the arrow has little or no lateral displacement leaving the bow. The feathers are reduced in size and the balance point is brought back towards the center since the purpose is not to hit straight on immediately, but to travel far.

125 تعذرى. Tazır is a hound in modern Turkish, but has an alternate meaning of "harrier". A harrier in English is a type of hawk. It may be Montagu's harrier, Circus pygargus or the hen harrier, Circus cyaneus or the Western marsh harrier, Circus aeruginosus or the Eastern marsh harrier, Circus spilonotus. Most could be seen both in India and in Iran.

126 Clearly there was an intention to discuss the types of sinew application relevant to each of the bows.

127 This is how pisé de terre or rammed earth walls are made. It would make a firm and durable structure.

128 pāy-e bote tir andāxtan ياىبوتهنير انداختن.

129 sahar صحر.
}

Rev. Artes Marciales Asiát., 11(1), 48-65 2016 


\section{Eleventh chapter}

Shooting in ox kasmal. First they hold the bow in the left hand. The arrows are kept in the sadaq ${ }^{130}$ meaning the quiver. He mounts the horse from his own right side [the rider's side] [It means his own right side as he faces the horse's head]. He places the target below the hand which is holding the bow, then he turns and shoots the arrow. He should turn the back from his waist upward. He should stick his lower body from waist to the saddle. ${ }^{131}$ Before he reaches the target, he rides faster for a short distance, takes out an arrow from the quiver, holds the bow, brings the horse to a gallop, turns back towards the back of the horse and shoots from the side of the buttocks of the horse. 132

\section{Twelfth chapter}

Shooting the qapag133. The qapag is a wooden pole with a length of circa fifteen gaz which is placed in a square. ${ }^{134}$ They place another piece of čalesp $\bar{a}^{135}$ wood on its top. On top of čalespā wood, they place a bowl full of gold [coins] or fabric of different colors. Then they mount a horse and gallop it in a straight line next to the wooden pole so that the horse gets acquainted with it. Then they take a soft bow with long limbs which is katebāš ${ }^{136}$ which means it is toke ${ }^{137}$. Katbās means it should have "flattened ears or tips" 138 because it prevents toke to go far. They gallop the horse and before reaching the wooden pole they bend on the horse so that the mane of the horse is below the right armpit of the rider and the face is towards the wooden pole and covers the wooden pole with the bow. They aim at it above the hand so that it reaches [the top of] the wooden pole and shoots. Unless the horse does not run straight and at a moderate pace, it is impossible to shoot. Another rider should ride in front of the horse so that the horse follows this horse well. ${ }^{139}$ They connect with the wooden pole above the hand. They should intensify the training so that they master it.

There are some requirements for an archer. First is talent. Second is interest. Third is the equipment. Fourth is an encouraging master who teaches the whole set of equipment and techniques of archery to the student and the student should also respect the master as required. The master should not refrain from teaching noble and good people. He should never teach the infidels.

\footnotetext{
130 صدق. This is from a Mongol word, sa'adak or saghadak, meaning bow case and quiver as a set. It entered several languages including Russian, Persian and Turkish. It is often used indiscriminately for bow case or quiver.

131 This is the normal technique for Middle Eastern and Central Asian riders. Contact with the horse is maintained with the thighs, knees and calves. This is possible because of the short stirrup leathers. What is not mentioned is the body would slightly rise from the seat of the saddle which would make turning at the waist easier.

132 This is clearly a form of qighaj قيغج as the Arabs called it or shooting at a slant at a ground target near the archer from a galloping horse. It is much more difficult than it sounds because a good shot has to be powerful. One Persian miniature shows a shield lying on the ground as a target (Latham \& Paterson, 1970, p. Pl. 10). The speed of the horse and the closeness of the target require split second timing.

133 قيق 13 it is a long wooden stick/pole planted in the city square on which a plate full of golden coins was placed which the mounted archers tried to shoot down while riding at full gallop; if the plate was shot down, the bowman could win a large prize. This is the Arabic and Turkish qabaq/kabak or gourd, which was the original inexpensive target of this exercise. Over time shooting at the gourd meant shooting at any target on top of a pole. Shahs and sultans made the target the prize so the winning archer received the coins or textiles as his prize.

134 This would be the long gaz referred to as 41 inches (Ouseley, 1821, p. 380 n. 205) or 1.04 meters giving a pole of 15.62 meters.

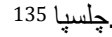

136 كتباش Pن Plied or folded tip in Azerbaijani.

137 توك . The meaning of this word is not clear. In Pashto it can mean "fully". In modern Turkish, tok means full. There is a verbal form in Arabic that means "being closely connected", tawakkud (توكد). The further comments by the author suggest that it is something specific. It may be that he is describing a bow that does not have much recurvature and is less sensitive to a poor draw. Arab Archery (Faris \& Elmer, 1945, pp. 135-137) recommends these bows for trick shooting and display. The advantages are that it would be easy to draw and an arrow that missed would not travel too far and be a danger to the spectators.

138 يُنس

139 This is a safety feature. One of the dangers of shooting from horse back at target on a pole is having your horse run into the pole. The critical time is just before you shoot when you are concentrating on turning drawing and aiming.
} 
Those who have problems in archery have problems in shooting "egg arrow" 140 and "glass arrow"141. If someone shoots an arrow and pierces a glass with it, this lowly person pierces an anvil ${ }^{142}$ with it. This seems an impossible act and no one believes it unless they see it. The egg arrow has a narrow shaft and similar to ātqu it should have no stains and it should not be fletched.

They place a raw egg on a wooden pole and stick the egg with moist mud so that the egg stays tight. The bow should have "short limbs"143 and very soft. He should stay away from the target with a distance of one bow. He places his left leg behind, puts the right leg forward, bends his left knee, draws the bow slowly and keeps bending his left knee but he does not rest on it on the ground. He draws the bow a bit so that it is rounded, holds his breath and shoots the arrow which will pass through the egg in a straight line. ${ }^{144}$

To shoot a poplar arrow through a wooden board, they should make the tip of the poplar arrow like a fish back ${ }^{145}$ and place some wax on its tip. They shoot it at a wooden board with a thickness of two fingers. The wooden board should not be hard. These are the poems by masters and if they memorize them and follow them in practice, it is better. The poems:

Aiming the target use the shoulder for it
Either you shoot for the shoulder or the target
$[\ldots]^{146}$

The person whose shoulders will be taken by the bow

If you want your arrow to pierce the centre of an anvil

Turn your body slightly and use both shoulders

Keep the special bow and arrows close to your hand

So that during battle you will have no excuses

Imitate the shape of a one-night crescent and take it with your thumb

Slash a jumping high-blooded steed ${ }^{147}$

With this [weapon], Bahrām conquered Byzantine Empire and Eastern Africa ${ }^{148}$

Iraj defeated two-tier enemy formation

From the fear of your arrow, the bird threw its feathers from its nest

Even if it builds its nest during flight

Grasp the bow grip like Bahrām and like Tāher

Then in the midnight you can shoot a grape from a grape cluster

Draw the bowstring towards the eye and wait a bit

Then in front of the army reviewer shake the two-tier [enemy] formation

When you draw the bow keep the bow grip straight

Keep the thumb relaxed and the rein ${ }^{149}$ loose $^{150}$

Poem

First the archer should draw and open

\footnotetext{
140 tir-e beyze تيربيضه.

141 tir-e šiše تيرشيشه تيشها.

142 sendān سندان.

143 kutāhxāne كوتناهن

144 This is like shooting through a glass, where the goal is to both to hit the target and not smash it. The arrow must be travelling perfectly straight when it hits the egg. Since it has no fletching, the release must be without any bias to the left or right because there are no feathers to correct the flight path. It is not just a test of accuracy but one of technique as well.

145 This type of arrowhead is mentioned in the $\bar{A} d \bar{a} b$ al-Harb by Fakhr-i Mudabbir as a standard type of arrowhead (McEwen, 1974, pp. 33, 97).

146 This part is missing in the text.

147 These two lines could mean, open your thumb and index finger into the shape of a crescent and then take the string. The other fingers would be out of the way at this point, tightly clenched. At the end of the shot your drawing arm should flex back like a rider whipping his horse.

148 zangbār دنكبار.

149 dahāne دهانه

150 The bow should be held straight, the bow-hand thumb should be relaxed and the reins should be loose (on the horse's neck.
} 
The bow with the thumb correctly

Not that in the day fighting the enemy

The bow appears hard and the archer weak attached).

Another prayer which is written on the bow is yō manaliheyf $f^{151} y \bar{a}$ salxus $\bar{a}^{\prime \prime 152}$ (........ Oh get

They should read the following verse: "In the name of Allah will it move and cast anchor. Surely my Lord is very Forgiving and Compassionate "153.

You should know that the governor of Neišābur says that he has heard from his own master that the archer should know twelve principles and if he does not know these principles, he should not do archery. He should keep three things tight, three things loose, three things straight and three things should be kept in one line. Three things which should be kept tight: first the bow grip should be kept tight, second the ..... ${ }^{154}$ should be kept tight and third when opening the right leg it should be kept tight on the ground. Three things which should be kept loose are: first the left side of the body, second the index finger ${ }^{155}$ of the hand grasping the bow handle and entering the bowarms. Three things which should be kept straight: first the right part of the face should be straight, second aiming should be straight and third the tip of the right elbow should be kept straight. Three things should be kept in one line: first both sides of the body should be kept in line, second both eyes and third both arms. There are eight other principles in archery: first standing, second the thumb, third the grasp, fourth drawing, fifth aiming, sixth shooting, seventh the bow and arrow, and eighth, the thumb ring meaning the thumb. When the archer starts to shoot the bow he first folds the left cuff and wraps it around the arm. He stands in a way so that the aim is in front of him. He puts the legs apart by placing the left leg in front. The tips of the toes of the right foot should face the same side as the left leg. The fronts of both legs should be in the same line. Some say that between two legs there should be a distance of one arrow's length between the left foot and the opposite thigh. He should stand so strongly that if someone hits him on the back with a hand, he does not move at all. And these two statements are important. Drawing and power are of three types: abu saidi156, bahrāmi and vaqāsi. In line with the thumb is abu saidi, but there are differences. The best thumb draw is the abu saidi style which consists of the way that after locking the thumb, the tip of the index finger is placed outside of the bowstring and it end of the [thumb] nail is placed behind the [index] finger in a way that the [index finger] nail is completely visible. This is exaggerated a bit but it means it should be place behind the [index] finger.

There are different types of grasping the bow grip which are tāheri ${ }^{157}$, vaqāsi ${ }^{158}$ and eshāqi159. The grasp tāheri is called "rounded fist" 160 and is attributed to Tāher Balxi. The eshāqi grasp is "hawk's claw grasp" 161 and this is the grip used by the Turks. The bahrāmi ${ }^{162}$ grip is even. There are two other different grasps which are different from these three grasps. One is the "lion's grasp" 163 and all five fingers are used in this grasp. Most people who are not proficient are using this type of grasp. ${ }^{164}$

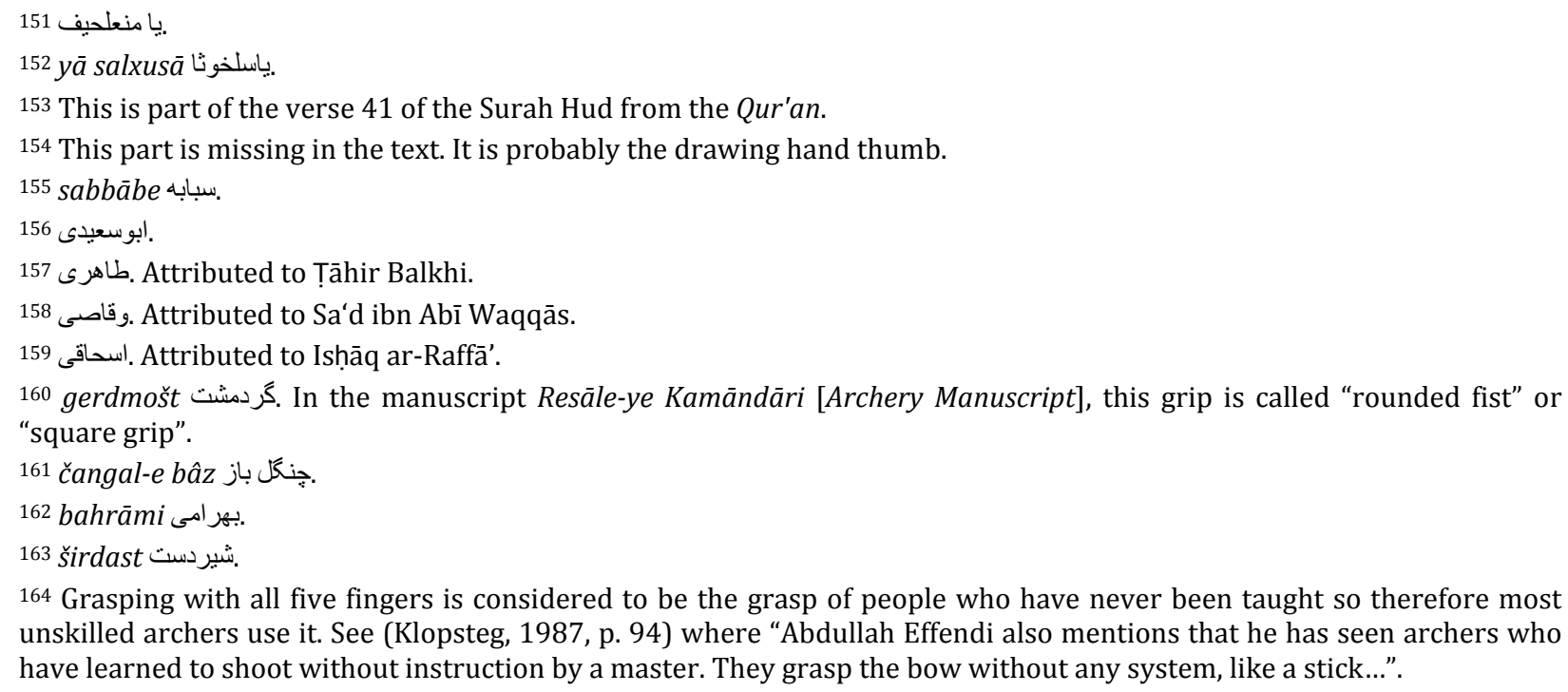
unskilled archers use it. See (Klopsteg, 1987, p. 94) where "Abdullah Effendi also mentions that he has seen archers who have learned to shoot without instruction by a master. They grasp the bow without any system, like a stick...". 
The other type is morabba' (square grasp) ${ }^{165}$ which requires holding the small finger, the ring finger, the index finger and the thumb are grasping the bow grip. Most people of this craft from Lahore use this type of grasp especially when using a heavy arrow. The best type of grasping is the tāheri grasp which requires holding the back of the bow grip between the fingers of the left hand [pressing against the proximal phalanges] so tight so that the tips of the fingers are close to bleeding. If they grasp the bow grip loosely in this type of grasping, the hand will be injured and the arrow will fly weakly and it does not fly fast. Some people say that the index finger should not be held inside. ${ }^{166}$

If the arrow tends to the right, they should turn the right leg to the left. If the arrow tends to the left, they turn the left leg to the right. If they place the thumb [of the drawing hand] above the bow grip, the arrow will fly low. If they place the thumb lower, the arrow will fly high. Therefore, the arrowhead, the bow grip, the thumb and elbow [of the drawing hand] should be in the same line. ${ }^{167}$

There are twelve other important requirements: first grasping the bow grip, second "shooting hard" 168 , third aiming at the target in a straight line, shooting with proper techniques ${ }^{169}$, fifth aiming even if the enemy is in front, sixth drawing with deportment ${ }^{170}$, seventh getting out of the bow like a champion, eighth stomping the front leg in the ground ${ }^{171}$, ninth "to have the adequate equipment" 172 , tenth respecting the bow, eleventh having performed ablution and twelfth saying "In the name of God" and "Thanks to God". They say that another prerequisite for drawing a bow is to draw it slowly so that it is done right.

The mistakes which make the arrow shake. These are four mistakes in the right hand. First if they hold the right hand loose, this will shake the arrow. Second if he is strongly slanted. Third if they make the hand heel rounded. ${ }^{173}$

There could be six deficiencies within the arrow. First when the nock is wide. ${ }^{174}$ Second when the arrowhead is too heavy. ${ }^{175}$ Third when one feather of the arrow is big and the other soft. ${ }^{176}$ Fourth when the string is torn. ${ }^{177}$ Fifth when the arrow shaft is eaten by woodworm. ${ }^{178}$ [Sixth] when they have mounted the arrow shaft with the arrowhead without taking enough care. ${ }^{179}$ In any of these cases, the arrow shakes. There could also be six deficiencies within the bow. First when the bowstring is rotten. Second when one of the "loops on the bow ears" 180 is wide and the other is tight. Third when the bowstring is uneven. ${ }^{181}$ Fourth when the bow is moist. ${ }^{182}$ Fifth when the bow becomes one arm $^{183}$. Sixth when there is a break in the bow. All these would also shake the

\footnotetext{
165 morabba' مربع.

166 Some systems have the index finger out of the path of the arrow. Others use the tips of the thumb and the index finger to form a guide for the arrow.

167 This is in conformity with the idea expressed in many manuals that the two hands and the drawing arm elbow should be in alignment for a good shot. When the two shoulders are included a very strong draw is assured.

168 saxt andāxtan سختانداختن.

169 nik andāxtan نيكىانداختن

170 bā soluk kešidan باسلوك كثنيدن.

171 This is popular with flight shooters who transfer their weight to the front leg as they release.

172 sāz-e movāfeq dāštan سازمو افقداشتن.

173 The author does not mention the fourth mistake.

${ }^{174} \mathrm{~A}$ wide nock would not sit straight on the string and the arrow may receive a slight deflection.

175 If the arrow head is too heavy, the arrow may flex too much as it leaves the bow.

176 Mismatched feathers always affect the flight of the arrow. In extreme cases, the arrow's tail may follow a spiral course.

177 This could either mean the arrow tears the string (dirt in the nock or the nock too tight) or a damaged string not properly accelerating the arrow.

178 The shaft's stiffness would be affected and it might start to break.

179 If the arrow head is not precisely aligned with the shaft, the arrow will wobble. The effect is as bad as a bent arrow.

180 halqe-ye guše حلقهك شكو.

181 This is when the thick and thin sections are not balanced with each other.

182 The bow will not perform well if moist. This is why so much trouble was taken to waterproof a composite bow.

183 The expression in Persian is "yek xāne gaštan" (to become one limb); according to the Digital Lexicon of Dehxodā, this is when the ears at the end of the bow limbs become one straight line with the bow limbs close to each side of the bow handle, which is a deficiency. This may also mean when the bow bends through the handle so the whole bow acts as one
} 
arrow. Anyone who overcomes these deficiencies will become an "archer who never misses his target" 184 and will master the craft of archery. Without ablution they should not practice archery.

The arrow is for the righteousness of the Messenger of God. Each arrow which leaves the bow should be accompanied by the statement "There is no God but Allah". The art of archery is the art of the great and is attributed to the Leader of the Believers [Hazrat Ali]. The grasp which is known as the grasp of Mortezā Ali is that originally the bow resembled kalle kamān and when the blessed hands of the Leader of the believers grasped that bow and pressed it, the shape of the bow grip appeared. With the length of two fingers he twisted the bow limbs until the kalle kamann so that they became wide. Then again he twisted the kalle kamān until the bow ears so that it became kalle kamān. Therefore it is called the grip of Mortezā Ali . . . . ${ }^{185}$ Serving the great in this craft, this lowly one learned some clear lessons and wrote them down so that no negligence can occur and they can easily be followed.

Sa'ad ibn Waqqās, who was one of the ten followers who would be in paradise ${ }^{186}$, was very proficient in the art of archery and lived in that unique and best era, had the illusion that no one was born in the world who was as proficient in archery as he was. ${ }^{187}$ The source of Trusteeship, the Ever Triumphant Lion of God, Ali the son of Tâlib, God forgive him, the Conqueror of Lands was informed about his [Sa'ad] opinion and he asked Sa'ad to go and shoot with their bows. Sa'ad accepted the offer and ordered that a rice salver should be hung from a large tree during a dark night for a distance of two hundred fifty paces. This is the distance where a fast riding messenger could not distinguish between two jars full of straw from each other and so they started to shoot from this distance. They ordered a man to get close to the tree and throw a stone at the salver it so that it made a sound. Immediately after the sound, the bowstring of the best archer of the period [referring to Sa'ad] shot three arrows each making three sounds from the salver. The "king of men"188 rubbed the hand of God behind the bow and shot at the target which pierced it and went through the other side. Then he shot two other arrows consecutively which did not make any sounds. Sa'ad who thought that the other two arrows had not made any sounds and hence missed the target, told the Ruler of the country ${ }^{189}$, "Let us go and look at the arrows to find out what happened." The shots of Sa'ad created three holes in the salver. What Hazrat-e Ali had done created one hole as all three arrows had passed through the same hole and the arrowheads of two of the arrows attached to the nocks of the other arrows making all three one arrow. Sa'ad was very surprised, the leader of believers said that God who created the world below and the world above always created someone more proficient than the other in any craft. The courageous companions of the Prophet, who mostly served Sa'ad, learned the science of archery from him. This way they learned the science of fame. A quatrain:

Oh my king, take your bow from your bow case 190

Take your arrow made of poplar ${ }^{191}$ from the quiver

Like a lion's claw hold your fist tight

Pull out the teeth from the head of your enemy ${ }^{192}$

limb. If the Digital Lexicon of Dehxodā is precisely right, then it means that the place where the ear joins the limb straightens out (this is the kasan gözü or kasan eye in a Turkish bow which is more prominent in Persian bows and Persian-influenced Indian bows).

184 hokmandāz حكمانداز.

185 This appears to be an explanation for the changing cross sections of the Persian bow and more specifically the shape of the grip with its ridge on the back.

186 ašare-ye mobašara عشره مبشره.

187 Sa'd ibn Abī Waqqāṣ was the most famous of the archers surrounding the Prophet. Many important ideas are attributed to him in archery literature.

188 It is the title of Hazrat-e Ali.

189 Referring to Hazrat-e Ali.

190 qorbān قربان.

191 xadang خدنگ.

192 This suggests the lion's claw grasp is not the grasp of the less proficient archer though it could just mean that it was popular when the quatrain was written, but had fallen out of favor. 
You should know that all parts of a bow have their own names as will be described below:

Drawing the bow completely is called making a circle ${ }^{193}$. The bowstring is called a loop ${ }^{194}$ as well. In describing tānk ${ }^{195}$, you should know that the weight of one pase-ye šāhjahāni196 equals five tānk. Whatever the amount of silk used for the bowstring is weighed and this is the same weight. Some say that this is only an estimation. Some ancient masters say they take a strung bow and attach a scale to the bowstring and place stones with the weight of twelve asār ${ }^{197}$. If the bowstring is drawn with the length of one arrow, this is equal to one tānk. ${ }^{198}$ God knows all.

The year 1191 [1771-1772 AD]

As I am the sinful slave

In the blessed month of Ramadan

The year 1212 [1797-1798 AD]

Ourang Vesāl Širāzi199

\section{Conclusion}

The author of this manual is at pains to establish that he is a practical archer reporting things from his own experience and that he continued using the art into old age. He may have written this as an old man with no chance to revise it and it could have suffered at the hands of copyists. We assume the two dates on the manuscript are of when the copies were done. Note that the two dates are the year 1191 [1771-1772 AD] and the year 1212 [1797-1798 AD] and the text has a seal of Ourang Vesāl Širāzi. Vesāl Širāzi was a Persian poet and calligrapher who lived from 1197-1262 Hijra (1783-1846 AD). It does not seem probable that he could have copied the text at the age of fourteen, but the two dates and a seal of the name of Vesāl Širāzi prove that the text was copied at a later date.

The author tries to be systematic and to a large extent succeeds, but the structure only emphasizes his occasional confusion. It is no surprise therefore that it contains many specific references to equipment. Bows, arrows and archers' rings are explained in some detail, which has resulted in information about how some types of arrows were used that has never before been published. The earth arrow, previously mentioned in other manuscripts, is given a particular usage. Its target is described and the range at which it is shot is precisely set out. Certain bows and their characteristics are specified for each type of shooting and the types of thumb ring known to the author are described and evaluated. A new form of contest, leys andāxtan, is mentioned but not defined. This manual is in some ways disjointed. There are sections missing and parts that appear to be mixed together. While some topics have detailed descriptions, others are just names without explanation. Despite being the work of an archer rather than an academic, there is clearly material from other works quoted or paraphrased. The twelfth chapter exemplifies this in being a miscellany of lists, descriptions, legendary contests, and poetry.

\footnotetext{
193 dāyere دايره. Compare the English phrase "to draw a bow full compass".

194 halqe حلقه; this could mean the loop because a bowstring could be seen as a loop bound in the middle leaving an eye at each end.

195 The tank is defined as 72 grains troy in (Thornton, 1823, p. 422). However, it is defined as 56 grains in (Thomas, 1874, pp. 69, n. 2). Kani, quoted in Turkish archery and the composite bow (Klopsteg, 1987, p. 56) says the suitable string for a bow of 12 fists would be 5 dirhems (at 49.3 grains per dirham). Kani quoting Abdullah on the same page reports that the Persians used a string weighing 4 dirhems for a bow of 150 rotl. Almost certainly these are quotes from much earlier authorities.

196 بيساششاهجهانى

197 آثار Asar, a Persian coin worth 6s. 8 d. sterling" (Mair, 1772, p. 399).

198 This last section is related to similar but more complete descriptions in other manuals for working out the ratio of the weight of the bowstring to the draw weight of the bow. See above, note Mair (1772, p. 193). Modern archers calculate from the breaking strain of a single strand of the bowstring material how many strands would be needed to matcher the weight of the bow. This figure is then multiplied by three for a flight-bow string and by four for a regular-bow string.

199 اورنح وصال شيرازى.
} 
However, despite the occasional confusion, the obscure vocabulary, and the odd clumsy description, the text is a mine of information. In the context of earlier and later manuscripts, it is more understandable than if it stood alone. It shows the continuity of the Persian archery tradition at least to the end of the eighteenth century and increases our knowledge of some of the details once commonplace that are now obscure. Despite being Persian in language, it is clearly directed partly at an Indian audience showing the popularity of Persian culture at the time. Its emphasis on proper teachers and continual practice are as true today as when it was written. The gradual increase in our knowledge of Persian archery is progressing through the discovery and translation of works like this one of Mohammad Zamān. Such manuals introduce new techniques and also confirm the pervasiveness of the basic forms of this ancient art.

\section{References}

Dwyer, B., \& Khorasani, M. M. (2012). Jāme al-Hadāyat Fi Elm al-Romāyat [Complete Guide Concerning the Science of Archery]. Quaderni Asiatici, 97, 45-60.

Dwyer, B., \& Khorasani, M. M. (2013). An Analysis of a Persian Archery Manuscript by Kapur Čand. Revista de Artes Marciales Asiáticas, 8(1), 1-12.

Dwyer, B., \& Khorasani, M. M. (2015). An Analysis of a Persian Archery Manuscript Titled Resāle-ye Qosnāmeh. Quaderni Asiatici, 112, 93-116.

Faris, N. A., \& Elmer, R. R. (1945). Arab Archery An Arabic Manuscript of about A.D. 1500 "A Book on the Excellence of the Bow and Arrow". Princeton: Princeton University Press.

Khorasani, M. M. (2013). Persian Archery and Swordsmanship: Historical Martial Arts of Iran. Frankfurt am Main: Niloufer Books.

Khorasani, M. M., \& Dwyer, B. (2012). A Persian Manuscript on Archery, Spear Fighting, Sword Tempering and Lance Fighting and Horsemanship by Šarif Mohammad the Son of Ahmad Mehdi. Pan-Asian Journal of Sports \& Physical Education, 4(1), 1-17.

Klopsteg, P. E. (1987). Turkish Archery and the Composite Bow. (3rd ed.). Manchester: Simon Archery Foundation.

Latham, J., \& Paterson, W. (1970). Saracen Archery. London: Holland Press.

Mair, J. (1772). Book-keeping methodised: or, a methodical treatise of merchant-accompts, according to the Italian form. (9th ed.). Dublin: H. Saunders.

McEwen, E. (1974). Persian Archery Texts: Chapter Eleven of the Fakhr-i Muddabir's Ādāb al-Ḥarb. Islamic Quarterly, XVII(3 \& 4).

McEwen, E. (1979). The chahār kham or 'four-curved' bow of India. In R. Elgood (Ed.), Islamic Arms and Armour (pp. 89-96). London: Scolar Press.

Mir'i, Hasan (1970). Āyne-ye Pahlavānnamā [The Mirror of Pahlavān]. Tehrān: Mihan

Ouseley, W. (1821). Travels in Various Countries of the East, More Particularly Persia (1810, 1811 and 1812) (Vol. 2). London: Rodwell and Martin-

Sharp, R. N. (1964). Farmanhāye Shāhanshāhān Hakhāmaneshi Ke Be Zabān-e Āryai (Pārsi Bāstān) Neveshte Shode [The Edicts of Achamenid Kings of Kings that were written in Aryan Language "Ancient Persian"]. Shiraz: Literature Department of Shiraz University Publications.

Thomas, E. (1874). Ancient Indian Weights (Vol. Marsden's Numismate Orientalia Part 1). London: Trübner \& Co.

Thornton, T. (1823). The East Indian calculator, or, Tables for assisting computation of batta, interest, commission, rent, wages, \&c. in Indian money. London: Kingsbury, Parbury, \& Allen.

Wulff, H. E. (1966). The Traditional Crafts of Persia. Cambridge, Massachusetts and London: Massachusetts Institute of Technology.

Yücel, Ü. (1998). Türk okçuluğu. Ankara: AYK Atatürk Kültür Merkezi Başkanlığı.

\section{Author's biographical data}

Dr. Manouchehr Moshtagh Khorasani (Germany) has written six books (four related to arms and armor), co-authored one book, and 156 print articles. His books include Persian Fire and Steel: Historical Firearms of Iran (in print), Persian Archery and Swordsmanship: The Historical Martial Arts of Iran, Lexicon of Arms and 
Armor from Iran: A Study of Symbols and Terminology (Winner of the World Book Prize of the Islamic Republic of Iran 2012), Antique Oriental and Arab Weapons and Armour: The Streshinskiy Collection, The Development of Controversies: From the Early Modern Period to Online Discussion Forums and Arms and Armor from Iran: The Bronze Age to the End of the Qajar Period (Winner of the World Book Prize of the Islamic Republic of Iran 2009). He is the founder and an active member of Razmafzar Organization dedicated to the study and academic research on historical Persian arms and armor and martial arts. E-mail: manouchehr@moshtaghkhorasani.com

Bede Dwyer (Australia) has pursued his interest in oriental archery for approximately 36 years of his adult life. In that time, he has researched the archery traditions of Turkey, Mamluk Egypt, Iran, Northern India, Mongolia, China and Korea. Rather than just compile information from old books, Bede has actively tested equipment and techniques and makes archers' rings, arrows, quivers and bow cases. Bede was the first person to shoot an arrow guide of the style of a Persian nāvak (Arabic majrā) in the American Flight Archery Tournament at Bonneville Flats in Utah. Bede also uses the Ottoman siper overdraw in flight shooting and briefly held a world distance record for shooting a hunting arrow with a traditional composite bow. For more than a decade Bede has been publishing articles in the Journal of the Society of Archer-Antiquaries on archaeological remains of archery equipment ranging from ancient repeating cross bows to medieval closed quivers. He is an active member of Razmafzar Organization dedicated to the study and academic research on historical Persian arms and armor and martial arts. E-mail: bededw@tpg.com.au 